\title{
Scientific-theoretical research approach to practical theology in South Africa: A contemporary overview
}

\begin{tabular}{|c|c|}
\hline \multicolumn{2}{|c|}{$\begin{array}{l}\text { Author: } \\
\text { Hennie J.C. Pieterse }{ }^{1,2}\end{array}$} \\
\hline \multicolumn{2}{|c|}{$\begin{array}{l}\text { Affiliations: } \\
{ }^{1} \text { Department of Philosophy, } \\
\text { Practical and Systematic } \\
\text { Theology, University of South } \\
\text { Africa, South Africa }\end{array}$} \\
\hline \multicolumn{2}{|c|}{$\begin{array}{l}{ }^{2} \text { Department Practical } \\
\text { Theology, Faculty of } \\
\text { Theology, University of } \\
\text { Pretoria, South Africa }\end{array}$} \\
\hline \multicolumn{2}{|c|}{$\begin{array}{l}\text { Research Project } \\
\text { Registration: } \\
\text { Project Leader: Y. Dreyer (D) } \\
\text { Project Number: } 2546930\end{array}$} \\
\hline \multicolumn{2}{|c|}{$\begin{array}{l}\text { Description: } \\
\text { Prof. Dr Pieterse is } \\
\text { participating in the resea } \\
\text { project, 'Gender Studies } \\
\text { Practical Theology Theor } \\
\text { Formation', directed by P } \\
\text { Dr Yolanda Dreyer, } \\
\text { Department of Practical } \\
\text { Theology, Faculty of } \\
\text { Theology, University of } \\
\text { Pretoria. }\end{array}$} \\
\hline \multicolumn{2}{|c|}{$\begin{array}{l}\text { Corresponding author: } \\
\text { Hennie Pieterse, } \\
\text { pietehjc@absamail.co.za }\end{array}$} \\
\hline \multicolumn{2}{|c|}{$\begin{array}{l}\text { Dates: } \\
\text { Received: } 09 \text { Dec. } 2016 \\
\text { Accepted: } 11 \text { Feb. } 2017 \\
\text { Published: } 18 \text { Aug. } 2017\end{array}$} \\
\hline \multicolumn{2}{|c|}{$\begin{array}{l}\text { How to cite this article: } \\
\text { Pieterse, H.J.C., 2017, } \\
\text { 'Scientific-theoretical } \\
\text { research approach to } \\
\text { practical theology in South } \\
\text { Africa: A contemporary } \\
\text { overview', HTS Teologiese } \\
\text { Studies/Theological Studies } \\
73(4), \text { a4483. https://doi. } \\
\text { org/10.4102/hts.v73i4.4483 }\end{array}$} \\
\hline \multicolumn{2}{|l|}{ Read online: } \\
\hline 口ifipis: & $\begin{array}{l}\text { Scan this QR } \\
\text { code with your } \\
\text { smart phone or } \\
\text { mobile device } \\
\text { to read online. }\end{array}$ \\
\hline
\end{tabular}

In this article, I present a critical literature study of the theoretical approach of practical theologians in South Africa to our discipline, in honour of Yolanda Dreyer on her 60th birthday. Some of my colleagues' approaches at the universities of Stellenbosch, Free State, Pretoria, Unisa and NWU (Potchefstroom campus) are discussed. All of them work with practical theological hermeneutics. The basic hermeneutic approach of Daniël Louw is widened with an integrated approach by Richard R. Osmer in which practical theology as a hermeneutic discipline also includes the empirical aspect which the action theory approach has contributed to the discussion. After discussing Louw's basic hermeneutic approach, all the other colleagues who basically accepted Osmer's approach in their publications are discussed. Important and new ground is being broken by contemporary colleagues, including research in public practical theology, without neglecting the focus on Christian congregations, and new work is being done at the grass roots level of African issues in our country.

\section{Introduction}

When I arrived in the Department of practical theology in the Faculty of Theology (B) at the University of Pretoria in 1976 as a lecturer, the approach to the discipline was according to the scriptural service model for the ministry of the church, focusing on pastors, elders and deacons (cf. Jonker 1968, 1981). The insights gleaned from the Bible for the ministry of the pastor and the church are guidelines for application in practice. But then the turn came in 1974, signalled by the book on the new approach to the discipline with the theory-praxis problem in the spotlight (Klostermann \& Zerfass 1974). Practical theology was then introduced as an academic discipline with an own object of study, theoretical base and an own methodology, in which the praxis could be researched with research tools of the social sciences in mostly qualitative projects. The main problem at that time was seen as the relation between theory and praxis (cf. Exeler \& Mette 1974; Greinacher 1974; Hawkes 1989; Heyns \& Pieterse 1990:23-32; Lehmann 1974). Within this new era of the discipline, different approaches developed, also in South Africa.

But now, since 1974, the context in South Africa and the perspective on knowledge worldwide have radically changed, which we experienced here since 1994, and our sociopolitical context is continually changing in the process of becoming a mature democracy. The postmodern view on knowledge is accepted by all contemporary practical theologians in this country, which opens up again the thinking on stories, metaphors, symbols, art and the possibility to imagine the Unseen (cf. Louw 2014). For a philosophical view on postmodernism, see, for instance, Lyotard (1984), Derrida (1976) and Ricoeur (1981; 1984; 1990a; 1990b). For the influence of postmodern thinking on theology, see, for instance, Ward (1997) and Caputo (2007). All contemporary practical theologians are aware of the post-colonial context in South Africa, and they also include studies on African situations and problems in their research. The post-colonial attitude implies that research is being done on problems in African contexts and Christian practices in those contexts, and that the curriculums are changed to include those research results and insights within a global discussion in our discipline. All of the contemporary practical theologians are also working on an interdisciplinary and multicultural basis. In this context and perspective on knowledge, I will do a critical literary research of the contemporary approaches to practical theology by practical theologians in our country. Theory and practice have moved towards each other and there is no longer a strong dualism between the two (Schoeman et al. 2012:133; Van Gelder 2007:100). It is rather interpreted as functioning within a bi-polar tension (Heitink 1998:69-71). This important aspect of research in our discipline is now formulated in a different way, such as the praxis of God, or praxis thinking or practical reasoning (Louw 2016:103-105). This relation between theological theory and Christian practice, or praxis thinking, which implies a theory behind it, is important in

Copyright: @ 2017. The Authors. Licensee: AOSIS. This work is licensed under the Creative Commons Attribution License. 
order to be directed in finding a suitable scientific-theoretical approach to the academic study of practical theology as a theological discipline, together with the other theological disciplines, at a public university. The theoretical approach to the discipline must be able to open up the possibility for suitable research by means of tested research tools. This article addresses the current state of approaches to the discipline by practical theologians in South Africa.

This contribution is in honour of Yolanda Dreyer. I have walked a long road with her as a colleague. I attended her first church service as a minister in the Nederduitsch Hervormde Kerk van Afrika in 1980 (cf. Pieterse 1981:28). We were colleagues for some time at the University of South Africa, and she was the head of the department of Practical Theology at the University of Pretoria during my work there as an extraordinary professor until 2014. I regard her as an outstanding academic researcher.

In the following paragraphs, I will first discuss the perspective of a philosophical--theological theory of practical theology, then the integrative perspective on different approaches, followed by the ritual theory. Lastly, I will discuss Yolanda Dreyer's approach, putting her in the realm of the different approaches.

\section{The philosophical-theological theoretical approach (practical theological hermeneutics)}

Daniël J. Louw (Stellenbosch University) works with a hermeneutical approach in our discipline, specialising in a sub-discipline of practical theology, namely pastoral theology. He described this approach already in 1993 (Louw 1993:70). But it is in his 2016 publication that he spells it out clearly. He works with the interplay between scientific thinking (scientia) and wisdom thinking (sapientia) (Louw 2016:100). Theology is not merely about a critical reflection, there is also a connection and interplay with wisdom, which is insight (Louw 2016:101). In theory formation with a hermeneutical approach, there should be place for both faith and reason within the paradigmatic framework of theologising - '... theology needs both critical reasoning and true discernment' (Louw 2016:102). This implies a 'zig-zag epistemology in praxis thinking' (Louw 2016:103). This way of thinking supersedes the principles of an explanatory cause-and-effect epistemology of logical reasoning:

The art and epistemology of hope operates because of the possibility of something new (novum); it assumes a kind of imagination and aesthetic creativity (fides quaerens imaginem: faith seeking imaginative forms of transcending; fides quaerens visum: faith seeking the vista of the Unseen). (Louw 2016:104)

Here, we meet the space of his postmodern thinking - his aesthetical and art approach in words and icons of imaging the Unseen (Louw 2014).

Wisdom knowledge acts in his hermeneutical approach as a kind of critical realism. Critical realism stands in a middle position between epistemological absolutism and epistemological relativeness (Louw 2016:104) - in Van Huyssteen's terms in his approach, called postfoundational (cf. Van Huyssteen 1999). In this way, critical realism in a practical theological realism connects science and wisdom in a fruitful exchange of knowledge. 'One can therefore say that methodology in wisdom thinking, and therefore in practical theology as an exponent of wisdom thinking, can be described as the hermeneutics of critical realism' (Louw 2016:104). Therefore, the study of the praxis of God as a theological proposition of practical theology cannot be understood in merely rational terms, because we study the encounter between God and humans in the praxis of God in his covenantal engagement with human life. Louw can now formulate "The "praxis of God" as a practical theological and academic endeavor' (Louw 2016:105). The object of study in practical theology is therefore the praxis of God.

He formulated practical words in praxis thinking and practical reasoning as follows:

Understanding/interpretation - a spiritual noetics of knowing; Communication/verbalizing - a spiritual encounter of beingwith; Acting - a spiritual engagement of attitudinal change and social transformation; Hoping - a spiritual expectation and anticipation of future; Imagining - a spiritual dynamics of creative poetics and aesthetic imaging; Seeing - a spiritual vision of prospection. (Louw 2016:106)

These practical verbs can be ecclesiological expressions of the praxis of God, which in essence is the outreach of God to people in need (Louw 2016:106).

Louw (2016) then formulated the basic modes of a ministerial and practical theological praxis:

The mode of kerugma or preaching; the mode of catechetics and didache; the mode of paraclesis or pastoral care; the mode of koinonia or fellowship; the mode of oikodomein or church development; the mode of marturia or witness, missional outreach; the mode of leitourgia or worship; the mode of diakonia or service. (p. 108)

Within these practical verbs and modes of ministry, action and theological principles for theory formation can be identified to outline the academic character of practical theology as a discipline at the university (Louw 2016:108). This design of practical theology is basically theory. However, to my mind, Louw has developed a fundamental approach as practical theological hermeneutics within which all the other approaches I am going to address are aspects of hermeneutical approach - focusing on certain specific issues. Louw also produced a great bulk of important and fundamental publications that will stand for time to come. There is a golden threat running through all his publications - the notion of hope.

In Stellenbosch, Johan Cilliers is working within this approach in homiletics, focusing on aesthetics, arts and play - which the postmodern era has opened up. Cilliers is making a great theoretical contribution with his contemporary publications 
in homiletics (cf., for instance, Cilliers 1994; 2000; 2004; 2008a; 2010; 2015). See the ritual approach to liturgy below for his contribution to liturgy.

The question is whether one can get a grip on the real context in which the ministerial actions are taking place with a theoretical approach alone, without empirical tools to research it. We can get a general idea of the context with a philosophical interpretation of it, but in practical theology where the ministry of the gospel is done in different contexts, we need a reliable inquiry of the specific context in a specific situation. The question exists furthermore, within practical theology as hermeneutics, whether certain functions in practical theology can be identified (Schoeman et al. 2012:133). Although Kobus Schoeman and his colleagues at the theological faculty at the University of the Free State build on Louw's hermeneutical approach (as most of us), they saw the answer to the question on the functions of the discipline in Osmer's integrative approach of practical theological hermeneutics (Osmer 2008).

\section{An integrative framework for practical theological hermeneutics}

Richard Osmer's hermeneutical approach to practical theology was inspired by the hermeneutical approach of Don S. Browning (1991) and the empirical contribution by Johannes A. Van der Ven (1993; see Osmer 2008:viii). Osmer's hermeneutical approach has a great influence on the work of contemporary practical theologians in South Africa. The important contribution of his approach is that he includes in his hermeneutical approach an empirical component. Osmer works with four core tasks in practical theological research, formulated in four questions: What is going on? Why is it going on? What ought to be going on? How might we respond? (Osmer 2008:4-12). The first task is the descriptiveempirical task; the second task is the interpretive task, the third task is the normative task and the fourth task is the pragmatic task.

The first task is described as the descriptive-empirical task, which is an expansion of the hermeneutical approach of Daniël Louw. In the action-theoretical approach which also includes a hermeneutical aspect, this approach was already there in the work of Gerben Heitink (1993), which also has an influence on South African practical theologians working with the hermeneutical approach. Browning's hermeneutical approach also includes an empirical task. Heitink's book is an integrative effort with three tasks, and Osmer's book has four tasks, which make it easier for postgraduate students to use in their research. Osmer's approach is therefore the culmination of the international discussion on the scientifictheoretical approach to our discipline during the last few decades. The theological character of practical theology was extensively worked out by Louw, as well as by Osmer. The contribution of the empirical aspect to this widely accepted hermeneutical approach was also provided by the action theory approach in South Africa with Unisa staff working together in collaboration with Van der Ven (Pieterse 1993; 2001; Van der Ven, Dreyer \& Pieterse 2004).

Osmer describes the new development in our understanding of hermeneutics, also for theology. In the past, the hermeneutical work was only done when we interpreted biblical texts in the biblical disciplines. It was called the rules for exegesis (cf. Pieterse 1979:22). But in theology, the idea of the 'new hermeneutics' as a broader understanding encompassing a whole theological discipline was introduced by Gerhard Ebeling (Pieterse 1979:34-81). Osmer refers to Hans-George Gadamer (1975), following up on Heidegger's hermeneutics, and introduced the second expansion of hermeneutics, 'the recognition of the interpretive dimension of scholarship' (Osmer 2008:22). Gadamer introduced the concept of a hermeneutical experience, which describes the interpretive activity that is open to 'encountering and learning, something genuinely new' (Osmer 2008:23). Gadamer introduced a hermeneutical circle in the process of understanding in academic work. 'Scholarship at its best partakes of this hermeneutical circle' (Osmer 2008:23). Hermeneutics is now broadened to the work of a whole discipline. Therefore, it makes sense to speak of practical theological hermeneutics:

New understanding emerges when scholars are open to hermeneutical experiences in which they become aware of the preunderstandings with which they begin their interpretative activity and are willing to put them at risk in a dialogical encounter with the objects, people, or texts they are interpreting. The hermeneutical, or interpretive, dimension of scholarship is widely acknowledgedtoday. (Osmer 2008:23)

\section{Osmer's Model as basic approach}

I will now discuss how contemporary practical theologians in South Africa work within the hermeneutical approach, making use of Osmer's approach. In this process, I will not discuss every person's work, but only the main trends as we can see it in the publications of some of the colleagues in a department.

In the Department of Practical Theology at the University of the Free Sate, Schoeman et al. (2012:133-136) discussed their work according to Osmer. 'These four tasks are used within the Department as broad guidelines for doing practical theology' (Schoeman et al. 2012:133). The advantage of Osmer's method is the bridging of the sub-disciplines, academy and ministry, and the interpretation of the interconnectedness of ministry (Schoeman et al. 2012:134). They could also add the space for empirical research in which Schoeman is well versed in. But they include to this method of Osmer the missional perspective of the missio Dei - the mission of God in this world to which we must join in our ministry to the poor and the devastated in our South African context (cf. Pieterse 2001:113).

With this approach to research in our discipline, they open up to the African context in which all South Africans are rooted. They call it their 'turn to Africa' (Schoeman et al. 
2012:135). In contemporary Africa, African identity is no longer defined by race. It must be understood that for both black and white South Africans, to be African today, does not involve race (Field 1998:52-56). The task of the researchers in this respect is now to internalise the experience of Africa, identifying with African church struggles and discerning the past history of colonisation and apartheid (Schoeman et al. 2012:134). For them to understand what is meant by a turn to Africa, they follow the insights in publications of Gathogo (2007:99), Ngong (2006:519) and Ikenye (2008:2). They discern the following 'metaphors' for their task: 'African theology of reconstruction; the quest for wholeness; deep grassroots African theology; African lived experience, and decolonisation of theory and practice in practical theology' (Schoeman et al. 2012:135). This turn to Africa has challenges for practical theology - the understanding of indigenous religion and how to understand the history of African culture during the ages of colonisation. But it is necessary 'for practical theology in South Africa and in particular the Department of Practical Theology at the UFS to take its praxis as the African context' (Schoeman et al. 2012:136).

The question is whether the permanent staff in this department at the UFS will find suitable co-researchers to research the African praxis on the grass root level in the black communities of our country.

It is important to list the different strategies of empirical inquiry, that is, the different tools of empirical research in qualitative research projects, which Osmer mentions in his discussion on the descriptive-empirical task of priestly listening (Osmer 2008:31). Many of the members of departments of practical theology, that will be discussed further on, are following the hermeneutical approach to practical theology (Osmer's model), but they use different empirical research strategies (empirical tools) for research in the sub-disciplines they are focusing on within the broad hermeneutical approach of Osmer in the postmodern view of knowledge. These strategies for empirical research are: life history/narrative research; case study research; ethnographic research (thick description of a cultural or social group); grounded theory research (analysis of the contents of sermons or interviews, sometimes in order to build a theory from praxis for new praxis); phenomenological research (to describe the essence of, for example, hospital patients' experience of the essence of the caring interaction with a nurse; and advocacy research (an explicit political agenda which seeks to contribute to social change). Within these research strategies, Osmer (2008:54) notes the following methods of research: interviews; participant observation; artefact analysis; spatial analysis; demographic analysis; and focus groups. Practical theologians in South Africa are making use of most of these strategies and methods for research within their subdisciplines.

The Department of Practical Theology at the University of Pretoria has black and white members on its staff. Cas Wepener is teaching and researching in preaching and liturgy. I will discuss his empirical strategy in preaching now. Later on, I will discuss his approach to liturgy research in a new paragraph. He is working with Osmer's model as can be seen in his own work and that of his students, for instance, Barnard (2016:143-154). In his book Kookpunt. Nadenke oor woede (Wepener 2015:26), he states that the book is researched with the typical practical theological approach (as described in this article above). The book is also a prophetic protest against the bad, violent things being done to people in our country. In his homiletical work, he makes use of the grounded theory strategy for analysing the contents of the sermons with coding, etc. In the research on sermons touching on the fury of church members of the violence and hurt that people experience, we made use of grounded theory analysis of the contents of the sermons (Wepener \& Pieterse 2016). Marileen Steyn, A student of Wepener, used the grounded theory strategy to analyse the contents of the sermons she researched (Steyn 2016). For this strategy of research in homiletics, see also Pieterse (2013).

Maake Masango is teaching pastoral care at the Department of Practical Theology, Pretoria University. He is teaching scores of black students in his honours course, which is theologically so good, that many of these students go on to write masters dissertations and doctoral theses. He is working with a narrative strategy in pastoral care, making use of the theories of Wimberley (2008), Gerkin (1997) and Pollard (1997), in which problems and themes at grass roots level in black communities are for the first time academically researched. He is delivering a great number of postgraduate students. Working with this narrative strategy, they listen to and interpret the stories of the respondents. Some of them are using case studies. They analyse the contents of the stories/ interviews collected in the case study with the grounded theory empirical strategy (see for instance, Banda 2016). Dr. Banda did very good research work and implemented the grounded theory strategy in a solid way as it was developed in homiletics to get a grip on the categories of content in the interview story data.

Julian Müller also uses the narrative strategy of research in pastoral care at this university. He has made a great impact in pastoral care and supervised scores of masters and doctoral students. He announced his narrative strategy in his book of 1996 (Müller 1996). He has grounded his narrative strategy in pastoral care with a solid philosophical and theological base of postfoundationalism using transversal rationality within the postfoundational approach of Van Huyssteen (1999). This empowers him to work with qualitative, contextual and interdisciplinary research of the stories of people in pastoral care (Müller 2003; 2009). He also makes use of the method of (new) ethnography in the narrative, postfoundational approach in practical theology which opens the way to see human lives as 'works of art' (Müller 2012:102). Müller and Karlijn Demasure of Leuven, at that time, had put the narrative strategy in pastoral care in the sphere of the hermeneutical approach to practical theology: 'It seems as if 
the hermeneutics of Ricoeur, social constructionism and the postfoundationalist approach to theology are all part of one family. These epistemological approaches support the narrative turn in pastoral care and conversation on several points' (Demasure \& Müller 2006:419). Julian worked for many years on a huge research project on HIV/AIDS. This research is a great contribution to our body of knowledge in our discipline. His contribution to the narrative research strategy in our discipline is the solid philosophical and theological base for it.

Johann Meylahn is teaching congregational studies and pastoral care in this department at the University of Pretoria. $\mathrm{He}$ is working with a strong philosophical base in the postmodern era and putting the results of profound studies on our tables regarding postfoundational practical theology as public Christology in the new contexts of today (see, for instance, Meylahn 2014; 2015). Meylahn is thinking in the contemporary context after the turns and shifts of recent times. The linguistic turn in philosophy and the human sciences (Heidegger, Derrida), the hermeneutical task of theology and practical theology, the shift out of the church into the public sphere, as well as the importance for interdisciplinary conversations put new challenges to practical theology (Meylahn 2014:1). He speaks of his view of the discipline of postfoundational practical theology as public Christology (Meylahn 2014). He describes postfoundational in a new, searching way:

Postfoundational, not in the sense of non-foundational, but in the sense of thinking through foundations like Heidegger's postmetaphysics, was a wounding of metaphysics ... or Derrida's postmetaphysics was the closure, not end, of metaphysics. Postfoundational practical theology is thinking through the foundations, religion, or metaphysics of the various life-worlds and witnessing their wounds or crucifixion because of what they invariably exclude and therefore their opening for the future. It is a witnessing not on the basis of a foundation, but on what 'God does in language or history' (God as the infinite desertification of language) as revealed in Christ, thus opening the life-world for what is to come: the kingdom to come. The postfoundational practical theologian is called to a Christological spirituality of not-being, through becoming neighbour to the marginal voices in the texts of the various publics (academia, society and church) and then bear witness and in faith offer testimony to the Christ-Ereignis, as he or she in hope continues reading texts in contexts in the time that remains. (p. 10)

Meylahn (2014:3) understands texts in the Ricoeurian way as also referring to persons, actions, experiences, practices and phenomena. What is theological about practical theology from this postfoundational perspective?

Postfoundational practical theology can be interpreted as being theological where God's action, revealed in Christ, is the hermeneutical centre of the whole approach ... a certain postmetaphysical interpretation of God informs the spirituality of the whole approach. A postmetaphysical interpretation of God, where the shift is away from 'transcending, patterns of action', has the possibility of being a non-religious method to interpret and engage lived religion critically. (Meylahn 2014:3)
How does Meylahn see the Christ-Ereignis (incarnation, crucifixion, resurrection and ascension)? He takes the Carmen Christi (Phlp 2:5-11) as a guide (Meylahn 2015:4). This view of Christ is that:

... he did not seek to be God (the Transcendent), but emptied (kenosis) himself of all divine content (Transcendent content). Thus, one has a movement here not from the flesh (text) towards God or Other, but an emptying of God or Other in the flesh (text), therefore one can speak of a radical immanence. (Meylahn 2015:4)

He was an empty symbol of the Other. (p. 4)

\section{The implications of this understanding of Jesus are:}

Jesus, interpreted as a radical-hyle, as a non-conceptual symbol, as an axiomatic heresy, can only be embraced in faith and as a gift (given without givenness). It is on the basis of such a postmetaphysical interpretation of Christ, with the metaphors of a radical-hyle and/or axiomatic heresy, that one can speak of a Christology or science of Christ ... as a non-philosophy or nonreligion: a Christology, where the logos has been crossed out, crucified. (p. 4)

Inter-textual reading is a spiritual reading with a hermeneutic of hope and love for marginal shadow stories. The intertextual reading where the Christ-Ereignis 'is read as a figure of the auto-deconstruction that happens in texts when and where one finds oneself neighbour to the marginal and shadow stories of these texts' (Meylahn 2015:8). This reading is a Christo-poetics when what happens in texts is interpreted through this figure of Christ. Christo-poetics is according to Meylahn (2015:8) a new creation of the resurrection through the crucifixion (deconstruction). This new creation is 'a temporary vulnerable creation in a permanent state of being crucified and rising (simul Justus et peccator). The new community is a Christo-poetics that is vulnerable and wounded' (Meylahn 2015):

As this is a possible spirituality of reading of all texts it can be seen as a public spirituality. It is a spiritual reading (Christpoetical reading) of public texts, academic texts, and of church texts of the various denominational traditions. (p. 8)

Practical theology as a postfoundational practical theology as a public Christology:

is done from the margins of the dominant discourses and therefore it could be seen as a Christology from the margins of the market to create spaces of kingdom life: life in fullness. (p. 1)

Johann Meylahn's work is new, exciting, theological in kind and has propelled us into the hard discussions of the immanent, secular discourses of our time.

Malan Nel has been working in this faculty at the University of Pretoria for many years. His specialised fields are congregational studies and youth ministry. In focusing on the local church, he wrote a book in 2005 on the identity of the local church (Nel 2005). This book teaches us his core views on the aforementioned subjects. Nel practices theology in the context of the local congregation; he emphases the God-given identity of the church, and that the church's being is missional. 
In the meantime, he has upgraded this book in the new context and understanding of our discipline in his publication of 2015 ( $\mathrm{Nel}$ 2015). On youth ministry, he introduced the idea that it is not a separate ministry alongside the ministry in the church, but that it is part of the whole ministry approach in the local church (Nel 2000). He is now working on an upgrade of this book into the contemporary context and way of thinking.

At the University of South Africa (Unisa), the staff consists of black and white members in the Department of Philosophy, Practical and Systematic Theology. Publications of Jaco Dreyer, Elsabé Kloppers, Elijah Baloyi and Gordon Dames are going to be discussed. Elsabé Kloppers states her hermeneutical approach to practical theology clearly (Kloppers 2001). The central question in a practical theological interpretation theory is the question of the mediation between the Christian tradition and practical experiences. The research will follow a praxis-theory-praxis spiral. She works with a critical-hermeneutical or hermeneutical-critical perspective (Kloppers 2001:463). She specialises in liturgy, church music and hymnology, and in homiletics with many good publications. Jaco Dreyer works with the hermeneutical approach of Heitink. Osmer's model, which he accepts, is basically the same, but is easier for students to employ in their research. He also specialises in Ricoeur's philosophy (cf. Dreyer 2012a). Jaco is the best informed practical theologian in empirical research in our country (cf. Van der Ven et al. 2004). He also put on the table the turn to African studies in our context, within the global discussion, with regard to race, gender and religious affiliation (Dreyer 2012b:513). In this contribution, he also stresses the development of a public practical theology which must be capable of facilitating involvement in South African contextual challenges (Dreyer 2012b:513). He is working on a design of a public practical theology in South Africa (cf. Dreyer 2007; 2011).

Magezi Elijah Baloyi is a prominent staff member of the discipline of practical theology at Unisa. He is responsible for pastoral care and is researching pastoral problems in the African context. A long list of prominent articles in this regard has already been published. He approaches a problem by referring to topical events in our day in the black community and makes use of critical literature studies. He is critically researching these problems and situations, but with a deep understanding of the African culture and with a positive, pastoral inclination to the people who are involved in his research. In his article on funerals where death is a uniting ritual for African people (Baloyi 2014a), he showed the positive effects of the funerals for mourning families and extended families coming from afar to a funeral. The article started with examples of how people came from far to attend the death of the Mozambican citizen Mido Macia'at the hands of the South African Police, and the death of the South African national soccer team's assistant coach (Baloyi 2014a:1). The article discussed the relevance of this study to practical theology and the African pastoral concept (Baloyi 2014a:2). He showed clearly how a funeral in the African context is a uniting factor to bring people together from long distances and invites people into a family, regardless of bad blood, flawed relationships and separation. He also, in another article which I have selected for my purposes, did a pastoral examination of the Christian church's response to fears and reactions to witchcraft (Baloyi 2014b). He discussed the reactions of groups of people to witchcraft: those in Christian churches who are campaigning against witchcraft, those who perceive witchcraft as a way to get rid of enemies and another group who see it as the root of all human misfortune (Baloyi 2014b:1); he describes the ways in which witchcraft appears and manifests itself to Africans, the consequences of such a belief, the views of Christian churches about it, the Biblical teachings on it; and he offers pastoral guidelines for a theological response to witchcraft and its lifethreating influence on people and communities (Baloyi 2014b:13-14). Elijah Baloyi is busy with a great contribution to pastoral research in African communities - building a source of knowledge that is long overdue.

Gordon Dames (2014) proposes an approach within the current understanding of practical theology in South Africa, to reach out to poverty-stricken families and communities with a transformative pastoral ministry. The central thesis of his book is a contextual, transformative and liberational postfoundationalist quest of deep answers for complex and pervasive challenges in the poverty-stricken communities. New frontiers for mission in the postmodern era should be entered in order to create sustainable communities where families and communities are faced with socioeconomic pathologies (Dames 2014:79-86, 104-111). In order to achieve this, a new future for intercultural theological training is necessary. This book addresses the problems with our ministry in the poor communities in a non-Western South Africa.

At the North-West University, Potchefstroom campus, work Ferdi Kruger (see, for instance, De Wet \& Kruger 2010; Kruger 2015), Gert Breed (see, for instance, Breed 2012) and Ben de Klerk. Fritz de Wet, who made a huge contribution to their approach to the subject, has unfortunately passed away (see, for instance, De Wet 2011). They are working according to Osmer's approach in practical theology. Heitink's contribution of the empirical-analytical, and the hermeneutical and the strategic aspects of research as Osmer has integrated it in his model, is their approach to our discipline, in line with most of the other researchers in South Africa (cf. De Klerk \& De Wet 2013:21-22). Ben de Klerk (2012) addresses the African cultural issue in his book on liturgy. He works in this book strictly according to Osmer's approach (De Klerk 2012:13):

The theology of a liturgy for Africa must be developed from an African perspective based on the Biblical revelation, relevant elements of the African world and life view that are not contradictory to the gospel. (De Klerk 2012:29)

\section{De Klerk (2012) put it clearly:}

The African symbols that are used in Christian churches are always accompanied by words that indicate the symbolism. These words are mostly prayers or even songs that contain a 
more detailed explanation. In rediscovering cultural symbolism liturgy has to discern and indicate what is contradictory to the gospel, but it must also be receptive to the assimilation of cultural symbolism that conform to the gospel. (p. 36)

\section{Worship as liturgical ritual}

In the sub-discipline of worship (liturgical studies), a new, exciting development has taken place in the last decade: the implementation of ritual theory and practice (cf. Barnard, Cilliers \& Wepener 2014; Lukken 1999; Wepener \& Van der Merwe 2009). This is a whole new approach in our discipline. Cas Wepener makes use of empirical methods too, namely participatory action research (participant observation) in worship services and the thick description of ethnographic research (Osmer 2008:51,54). Johan Cilliers is active with this approach in liturgy (cf., for instance, Cilliers 2008b; 2008c). Cas Wepener is a leading figure in South Africa and internationally within this approach, still in the postmodern, hermeneutical approach to our discipline, and is also doing research in the African culture (cf. inter alia Wepener 2006a; 2006b; Wepener, Mbaya \& Barnard 2011).

The basic elements of ritual are sign, symbol, symbolic action, symbolic speech acts and rituals. The typical characteristic of a ritual is repetition, myth (story) and ritual, and the dimensions of ritual (Wepener \& Van der Merwe 2009:197). A sign has a plain, unmistakable meaning such as a traffic sign; a symbol has in a certain context, numerous, more, plural meanings - it speaks for itself and brings the past and the present together in our interpretation; symbolic action is action by human beings in bodily expression, etc., filled with meaning where people are the agents of the process of symbolising; symbolic language (speech acts) is ambiguous, it calls up new worlds, new realities and opens up new horizons and realities that are more than that our rational understanding of realty could imagine. In any ritual symbol, symbolic action and symbolic language are functioning (Wepener \& Van der Merwe 2009:198-201). Humans as playing beings are important in ritual theory and practice:

The one who plays breaks open a closed reality and reaches outside of himself. This is the shortest circumscription of the act of symbolizing, literally (the Greek word sum-ballein) the bringing together of different domains. We live in a closed domain that is broken open through symbolizing, viz. through symbolic speech acts, symbolic acting and symbols. (Barnard et al. 2014:40)

With this ritual research approach not only church activities can be researched but also activities in public life.

\section{Yolanda Dreyer - First in new developments}

Yolanda Dreyer was the first woman who became an ordained minister in the Afrikaans-speaking Dutch Reformed churches in South Africa. She was also the first woman who was the head of the department of Practical Theology at the University of Pretoria, and she was the first woman who became the chairperson of the Society of Practical Theology in South Africa. This testifies for' her balanced personality and her brilliant career as professor in practical theology - also the trust her colleagues have in her. She also did research in New Testament studies and contributed in this field as well (cf., for instance, Van Aarde \& Dreyer 2010). This article is an example of her interpretation of the gospel message which opens up her contribution on the equal position of women today, as well as her pastoral outreach to those who are emotionally wounded. The state of Matthean studies today is at the crossroads. In order to proceed beyond the crossroads, the authors work with Paul Ricoeur's notion of the 'hermeneutical arc' in this article. It is necessary to apply 'the hermeneutical aspect of a willingness to suspect and a willingness to listen' (Van Aarde \& Dreyer 2010:1). The relationship between women and the disciples in this gospel is the focus of the article, and it is therefore important to approach with suspicion the outdated values, and listen 'to unarticulated voices that remain hidden because of ideologies that render them inaudible' (Van Aarde \& Dreyer 2010:1). The focus should be on morals. This article put facets in Matthew in a new light. Many contributions on the position of women in marriage and their position otherwise are done by Yolanda. In one of these articles, she also put her hermeneutical approach to our discipline on the table (Dreyer 2011). In this article, she discusses the different methodological approaches to feminism and chooses for a liberation-hermeneutical feminism (Dreyer 2011:4). The core of meaning is connected to self-perception and spirituality which determines one's identity (Dreyer 2011:1). She convincingly argued that patriarchal marriage is outdated. An example of the huge contribution she is making to human dignity and, for example, her views on marriage and same sex relationships is the essence of her article of 2008 (cf. Dreyer 2008). In this article, she appeals for privacy instead of categorising people 'such as crazy people, criminals, women, married women, unmarried women, divorced women, homosexuals, adolescents and many more' (734):

Postmodern discourse requires that people are disengaged from these groups or 'types' for the sake of their human dignity. Their communal existence in groups, on the other hand, should be redefined as whole and healthy rather than deviating from the norm, as the typification suggests. Priority should be given to the particular one rather than the institutional many and to the person rather than the institution. Also in the church the interests of the institution should take a second place to people. (p. 735)

In 2016, Yolanda's denomination decided at their general meeting (Algemene Vergadering) that gay people may be ministers (predikante) without being celibate in congregations which call them as their ministers (Jackson 2016:5). This decision took place with a large majority while other denominations are still bickering on this issue.

Yolanda also works with Osmer's approach to the discipline and her students are doing empirical researches with qualitative methods that suit their subject of research (See, for instance, Van Staden 2013). I honour her as a good friend, a great colleague and an excellent practical theologian. 


\section{Conclusion}

All the practical theologians in South Africa, whose theoretical approaches to the discipline are discussed, work within a hermeneutical practical theology. The insights gained from each researcher enrich our body of knowledge and our understanding of our task in the contemporary complex situation of our society and our Christian communities.

\section{Acknowledgements Competing interests}

The author declares that he has no financial or personal relationships which may have inappropriately influenced him in writing this article.

\section{References}

Baloyi, M.E., 2014a, 'Distance no impediment for funerals: Death as a uniting ritual for African people - A pastoral study', Verbum et Ecclesisa 35(1), Art. \#1248, 1-7. African people - A pastoral study', Ver
https://doi.org/10.4102/ve.v35i1.1248

Baloyi, M.E., 2014b, 'A pastoral examination of the Christian Church's response to fears of and reactions to witchcraft amongst African people in the Limpopo province of South Africa', HTS Teologiese Studies/Theological Studies 70(2), Art. province of South Africa', HTS Teologiese Studies/Theo
$\# 1317,1-9$. https://doi.org/10.4102/hts.v70i2.1317

Banda, P., 2016, “"Child defilement" in ecclesial contexts in Zambia: A pastoral perspective', PhD thesis, University of Pretoria.

Barnard, J., 2016, 'Liturgie as ontmoetingsruimte. Die erediens as die identiteitsvormende en lewensimpakterende ontmoetingsgebeure', MTh dissertation, University of Pretoria.

Barnard, M., Cilliers, J. \& Wepener, C., 2014, Worship in the network culture. Liturgical ritual studies. Fields and methods, concepts and metaphors, Peeters, Leuven.

Breed, G., 2012, 'Begronde bedieningsmodel vir die diakonie van die gemeente', In die Skriflig 45(4), 775-801.

Browning, D.S., 1991, A fundamental practical theology. Descriptive and strategic proposals, Fortress Press, Minneapolis, MN.

Caputo, J.D., 2007, What would Jesus deconstruct: The good news of postmodernity in the church, Baker Academic, Grand Rapids, MI.

Cilliers, J.H., 1994, 'Prediking as resepsie-estetika: 'n verkenning', Ned. Geref. Teologiese Tydskrif 35(4), 583-588.

Cilliers, J.H., 2000, 'The beauty of imagined meaning: Profiling practical theological aesthetics', Practical Theology in South Africa 24(1), 32-47.

Cilliers, J.H., 2004, The living voice of the gospel. Revisiting the basic principles of preaching, SUN Press, Stellenbosch.

Cilliers, J.H., 2008a, 'Skrifbeskouing en Skrifhantering. Perspktiewe op 'n hermeneutiek van verwagting', Verbum et Ecclesia 29(1), 62-76. https://doi.org/10.4102/ve. v29i1.5

Cilliers, J.H., 2008b, 'Worshipping in the townships - A case study for the liminality of liturgy', Journal of Theology for Southern Africa 132, 72-85.

Cilliers, J.H., 2008c, 'Silence is golden. Liturgy beyond the edge of language', Practical Theology in South Africa 23(1), 62-76.

Cilliers, J.H., 2010, 'Clowning in the pulpit? Contours of a comic vision of preaching', Scriptura 101, 189-199. https://doi.org/10.7833/101-0-632

Cilliers, J.H., 2015, 'Where have all the prophets gone? Perspectives on political preaching', Stellenbosch Theological Journal 1(2), 367-383. https://doi. preaching', Stellenbosch Theolog
org/10.17570/stj.2015.v1n2.a17

Dames, G.E., 2014, A contextual transformative practical theology in South Africa, Acad SA Publishing, Parow.

De Klerk, B.J., 2012, Liturgical involvement in society, Potchefstroomse Teologiese Publikasies, Noordbrug.

De Klerk, B.J. \& de Wet, F.W. (reds.), 2013, Met die oog op God. Voorveronderstellings van die reformatoriese invalshoek op Praktiese Teologie, Potchefstroomse Teologiese Publikasies, Noordbrug.

Demasure, K. \& Müller, J., 2006, 'Perspectives in support of the narrative turn in pastoral care', Ned.Geref. Teologiese Tydskrif, Deel 47(3\&4), 410-419.

Derrida, J., 1976, Of grammatology, Johns Hopkins University Press, Baltimore, MD.

De Wet, F.W., 2011, Hoe lieflik is die Lig, 'n Verkenning van die dieptevlak van die homiletiese proses, Potcefstroomse Teologiese Publikasies, Potchefstroom.

De Wet, F.W. \& Kruger, F.P., 2010, "n Prakties-teologiese perspektief op die handeling van kerklike besluitneming: Verkenning en normatiewe gesigspunte', In die Skriflig 44(1), 1-25. https://doi.org/10.4102/ids.v44i1.134

Dreyer, J.S., 2007, 'The national policy on religion and education in South Africa: Reflections from a public practical theology', Practical Theology in South Africa 22(2), 40-60.
Dreyer, J.S., 2011, 'Public theology and the translation imperative: A Ricoeurian perspective', HTS Teologiese Studies/Theological Studies 67(3), Art \#1157, 1-8. perspective,
https://doi.org/10.4102/hts.v67i3.1157

Dreyer, J.S., 2012a, 'Forgiveness: A Ricoeurian perspective', Theologia Viatorum 36(1), 141-168.

Dreyer, J.S., 2012b, 'South Africa', in B.J. Miller-McLemore (ed.), The Wiley-Blackwell companion to practical theology, Blackwell, Oxford, pp. 505-514.

Dreyer, Y., 2008, “"De-centre-ring" sexual differences in public and ecclesial discourses on marriage', HTS Teologiese Studies/Theological Studies 64(2), 715-738. https:// doi.org/10.4102/hts.v64i2.41

Dreyer, Y., 2011, 'Women's spirituality and feminist theology: A hermeneutic of suspicion applied to "patriarchal marriage"', HTS Teologiese Studies/Theological Studies 67(3), Art. \#1104, 1-5. https://doi.org/10.4102/hts.v67i3.1104

Exeler, A. \& Mette, N., 1974, 'Das Theorie-Praxis-Problem in der Praktische Theologie des 18. und 19. Jahrhunderts', in F. Klostermann \& R. Zerfass (eds.), Praktische Theologie heute, pp. 65-80, Kaiser, München.

Field, D.N., 1998, 'On being Euro-African. Theologian identity and vocation in postapartheid South Africa', Journal of Theology for Southern Africa 102, 45-59.

Gadamer, H.-G., 1975, Truth and method, Continuum, New York.

Gathogo, J., 2007, 'African theology of reconstruction as a practical theology for all', Practical Theology in South Africa 24(2), 99-121.

Gerkin, C.V., 1997, An introduction to pastoral care, Abingdon, Nashville, TN.

Greinacher, N., 1974, 'Theorie-Praxis-Verhältnis in der Praktische Theologie', in F. Klostermann \& R. Zerfass (eds.), Praktische Theologie heute, pp. 103-118, Kaiser, München.

Hawkes, G., 1989, 'The relationship between theology and practice in Southern Africa', Journal of Theology for Southern Africa 68, 29-39.

Heitink, G., 1993, Praktische theologie - geschiedenis, theorie, handelingsvelden, Kok, Kampen.

Heitink, G., 1998, Pastorale zorg, Kok, Kampen.

Heyns, L.M. \& Pieterse, H.J.C., 1990, A primer in practical theology, Gnosis, Pretoria.

Ikenye, N.J.B., 2008, Pastoral theology: Rediscovering African models and methods, Zapf., Eldoret.

Jackson, N., 2016, 'Drie groepe wil besluit behou', Kerkbode, 21 Oktober 2016, p. 5.

Jonker, W.D., 1968, Theologie en praktijk, Kok, Kampen.

Jonker, W.D., 1981, In diens van die Woord, NG Kerkboekhandel, Pretoria.

Kloppers, E., 2001, 'The intelligent initiative of deciphering - Praktiese Teologie as hermeneuties-kritiese telogie', Scriptura 78, 457-466. https://doi.org/10.7833/78$0-696$

Klostermann, F. \& Zerfass, R. (eds.), 1974, Praktische Theologie heute, Kaiser, München.

Kruger, F.P., 2015, 'The preacher's vulnerable attitudes in naming reality in a neglected society', Verbum et Ecclesia 36(1), 1-9. https://doi.org/10.4102/ve.v36i1.1383

Lehmann, K., 1974, 'Das Theorie-Praxis-Problem und die Begründung der Praktischen Theologie', in F. Klostermann \& R. Zerfass (eds.), Praktische Theologie heute, pp. 81-102, Kaiser, München.

Louw, D.J., 1993, Pastoraat as ontmoeting. Ontwerp vir 'n basisteorie, antropologie, metode en terapie, RGN-Uitgewery, Pretoria.

Louw, D.J., 2014, Icons. Imaging the Unseen. On beauty and healing of life, body and soul, SUN Press, Stellenbosch.

Louw, D.J., 2016, Wholeness in Hope Care. On nurturing the beauty of the soul in spiritual healing, Lit Verlag, Zürich.

Lukken, G., 1999, Rituelen in overvloed. Een kritische bezinning op de plaats en de gestalte van het christelijke ritueel in onze cultuur, Gooi \& Sticht, Baarn.

Lyotard, J.-F., 1984, The postmodern condition: A report on knowledge, Minnesota University Press, Minneapolis, MN.

Meylahn, J.-A., 2014, 'Postfoundational practical theology as public Christology', Verbum et Ecclesia 35(2), Art. \#875, 1-11. https://doi.org/10.4102/ve.v35i2.875

Meylahn, J.-A., 2015, 'After God: Practical theology as a public Christology from the margins of the market', HTS Teologiese Studies/Theological Studies 71(3), Art. \#2975, 1-9. https://doi.org/10.4102/hts.v71i3.2975

Müller, J., 1996, Om tot verhaal te kom: Pastorale gesinsterapie, RGN-Uitgewery, Pretoria.

Müller, J., 2003, 'HIV/AIDS, narrative practical theology, and postfoundationalism: The emergence of a new story', HTS 60(172), 293-306.

Müller, J., 2009, Postfoundationalism as a practical way of interdisciplinary dialogue: Narrative research on HIV and Aids, CG Publishers, Warren, Michigan

Müller, J., 2012, 'Transversaliteit as oriënteringspunt vir die waarneem van die Prakties-Teologiese landskap', in D. Human \& D. Veldsman (eds.), Oor jou afdrukke. Met waardering vir Cas Vos se teologies-poëtiese bydrae, pp. 91-105, Universiteit Met waardering vir Cas
van Pretoria, Pretoria.

Nel, M., 2000, Youth ministry, Design Books, Pretoria.

Nel, M., 2005, Who are we? Understanding and finding identity in the local church, Kitskopie, Pretoria.

Nel, M., 2015, Identity driven churches, Bybelkor, Wellington.

Ngong, D.T., 2006, 'In quest of wholeness: African Christian in the New Christianity', Review and Expositor 103(3), 519-540. https://doi.org/10.1177/003463730610300305 
Osmer, R.R., 2008, Practical theology. An introduction, Eerdmans, Grand Rapids, MI. Pieterse, H.J.C., 1979, Skrifverstaan en prediking, NG-Kerkboekhandel, Pretoria.

Pieterse, H.J.C., 1981, Die daad by die Woord, NG Kerkboekhandel, Pretoria.

Pieterse, H.J.C, 1993, Praktiese teologie as kommunikatiewe handelingsteorie, RGNUitgewers, Pretoria.

Pieterse, H.J.C., 2001, Preaching in a context of poverty, Unisa Press, Pretoria.

Pieterse, H.J.C., 2013, 'An emerging grounded theory for preaching on poverty in South Africa with Matthew 25:31-46 as sermon text', Acta Theologica 33(1), 175-195

Pollard, N., 1997, Evangelism made slightly difficult, Intervarsity Press, Leicester, UK/ Westmont, IL.

Ricoeur, P., 1981, Hermeneutics and the human sciences, Cambridge University Press, Cambridge.

Ricoeur, P., 1984, Time and narrative, vol. 1, The University of Chicago Press, Chicago, IL.

Ricoeur, P., 1990a, Time and narrative, vol. 2, The University of Chicago Press, Chicago, IL.

Ricoeur, P., 1990b, Time and narrative, vol.3, The University of Chicago Press, Chicago, IL.

Schoeman, K., Laubscher, M., Pali, J. \& Van den Berg, J.-A., 2012, 'Practical theology at a public university. The road travelled and the road ahead at the university of the Free Sate', in R. Venter \& F. Tolmie (eds.), Transforming theological knowledge. Essays on theology and the university after apartheid, pp. 127-143, SUN MeDIA Bloemfontein, Bloemfontein.

Steyn, M., 2016, 'A grounded theory analysis of sermons on racism', MDiv dissertation, University of Pretoria.

Van Aarde, A.G. \& Dreyer, Y., 2010, 'Matthew studies today - A willingness to suspect and a willingness to listen', HTS Teologiese Studies/Theological Studies 66(1), Art. \# 820, 1-10. https://doi.org/10.4102/hts.v66i2.820
Van der Ven, J.A., 1993, Practical theology: An empirical approach, Kok Pharos, Kampen.

Van der Ven, J.A., Dreyer, J.S. \& Pieterse, H.J.C., 2004, Is there a God of Human Rights? The complex relationship between Human Rights and Religion: A South African Case, Brill, Leiden.

Van Gelder, C., 2007, The ministry of the missional church, Baker Books, Grand Rapids, MI.

Van Huyssteen, J.W., 1999, The shaping of rationality: Toward interdisciplinarity in theology and science, Eerdmans, Grand Rapids, MI.

Van Staden, J.M., 2013, 'Gesinsbediening as bedieningsvennoot tussen gemeentes en gesinne', PhD thesis, University of Pretoria, Pretoria.

Ward, G. (ed.), 1997, The postmodern God: A theological reader, Blackwell, Oxford.

Wepener, C. \& van der Merwe, J. (reds.), 2009, Ontdekkings in die erediens, Lux Verbi, Wellington.

Wepener, C.J., 2006a, 'Participation and power. Opportunities for method and theory in liturgical research from a changing (Dutch Reformed) South African liturgical landscape', Jaarboek voor liturgieonderzoek 22, 58-61.

Wepener, C.J., 2006b, 'Ritual route markers for reconciliation. Insights from a South African exploration', Studia liturgica 36(2), 173-184.

Wepener, C.J., 2015, Kookpunt. Nadenke oor woede, Bybelkor, Wellington.

Wepener, C.J., Mbaya, H. \& Barnard, M., 2011, 'Worship in the Corinthian Church (AIC) in Phepheni, Eastern Cape, South Africa', Studia liturgia 41(2), 252-273.

Wepener, C.J. \& Pieterse, H.J.C., 2016, 'Angry Preaching', Paper delivered at the Societas Homiletica, March 2016, University of Stellenbosch, submitted for publication to the International Journal of Public Theology.

Wimberley, E.P., 2008, African American Pastoral Care, rev. edn., Abingdon, Nashville, TN. 